\title{
INTAKE DEVICE OF NATURAL VENTILATION SYSTEM OF LIVESTOCK PREMISES IN WINDY WEATHER AND COLD SEASON
}

\author{
Nina Toncheva ${ }^{1}$, Andrei Samsonov ${ }^{2}$, Maksim Ivanov ${ }^{2}$ \\ ${ }^{1}$ Chuvash State Pedagogical University named after I. Y. Yakovlev, Russia; \\ ${ }^{2}$ Volga branch of Moscow Automobile Road Construction State University (MADI), Russia \\ toncheva01@yandex.ru,dyha2004@mail.ru,ivanovmu84@mail.ru
}

\begin{abstract}
The supply of external air to the livestock building in windy weather and in cold season is one of the problems of the natural ventilation system. In windy weather there is overcooling of the lower zone due to air pressurization from the windward side into the room through the supply devices, and in the cold season at low external temperatures a significant temperature drop occurs in the height of the livestock room. This problem can be solved by using a supply device, the intake pipe of which is equipped with a control valve to prevent overcooling of the lower zone of the room in windy weather, and in order to prevent a significant temperature difference in the cold season, the duct is elongated and installed parallel to the pitched roof of the livestock building. The control valve consists of two flaps pivotally mounted on the fixed shaft of the air intake pipe. The valves of the control valve are connected by a calibrated tension spring and are directed to the inlet of the air intake pipe with the possibility of their opening from the maximum approach to the maximum diluted position. This article presents the scheme and principle of operation, the results of theoretical research on the study of the intake device of the natural ventilation system of the livestock premise. The heat and mass change in the proposed air intake device is considered, the dependence of the degree of external air heating in the air intake device $\Delta t_{H}$ depending on the external air speed $v$ and the air supply duct length $x$ is obtained, and dependency graphs are constructed. It is confirmed that $\Delta t_{t}$ heating degree of the livestock premise decreases with the increase of the external air speed $v$ and with the increase of $x$ duct length it increases. It is noted that if the length $x$ of the supply air duct is equal to 3 meters, the $\Delta t_{u}$ heating degree of the livestock premise is $5.6^{\circ} \mathrm{C}$ at $-20^{\circ} \mathrm{C}$ external temperature.
\end{abstract}

Keywords: livestock premises, natural ventilation, intake device.

\section{Introduction}

One of the most important conditions for increasing the efficiency of livestock production is the creation and maintenance of a set microclimate in the farm premises and complexes. The natural ventilation system (NVS) is the most common ventilation system of a livestock building due to its main advantages: simplicity and low operating costs or their absence. At the same time, the supply of external air to the livestock building in windy weather and in cold season is one of the problems of the natural ventilation system. In windy weather there is hypothermia of the lower zone due to boost of air from the windward side into the room through the supply devices. The significant temperature difference occurs along the height of the livestock building in cold season at low external temperatures. The air intake device of external air should include the possibility of heating it. In this regard, many researchers have shown interest in such systems [1-9]. However, the known natural ventilation schemes do not fully provide the necessary air exchange and the standard temperature of the livestock building in windy weather and in the cold season.

The aim of this work is theoretical justification of the supply device parameters of the natural ventilation system of the livestock building providing the standard temperature in windy weather and in the cold season.

\section{Materials and methods}

In order to solve this problem, it is proposed to equip the livestock building with an SEV supply device (Fig. 1). The air intake pipe is equipped with a control valve [10] to prevent overcooling of the lower zone of the room in windy weather in the supply device installed in the wall opening of the livestock building (Fig. 2). In order to prevent a significant temperature difference in the cold season, the duct is elongated and installed parallel to the pitched roof of the livestock building. The control valve consists of two flaps pivotally mounted on a fixed shaft of the air intake pipe. The flaps of the control valve are connected by a calibrated tension spring and are directed to the inlet of the air intake pipe with the possibility of their opening from the maximum approach to the maximum diluted position. 


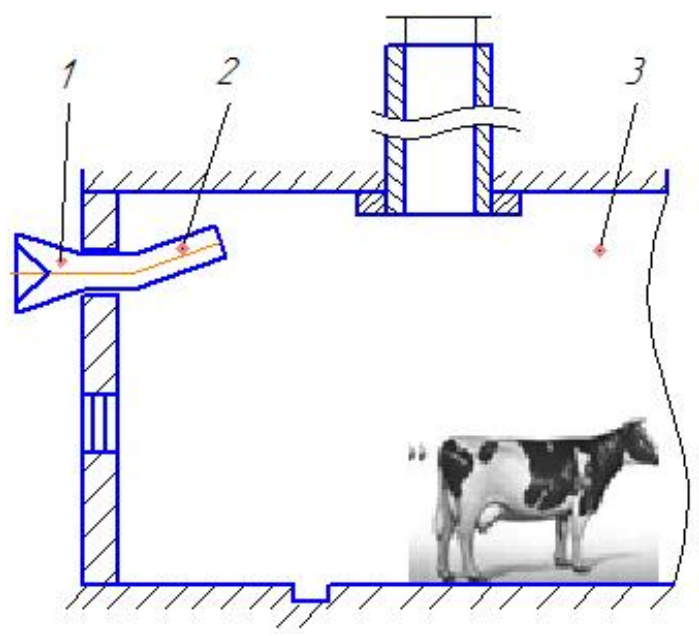

Fig. 1. Cross section of the livestock building equipped with a supply device: 1 - air intake pipe; 2 - duct; 3 - livestock building

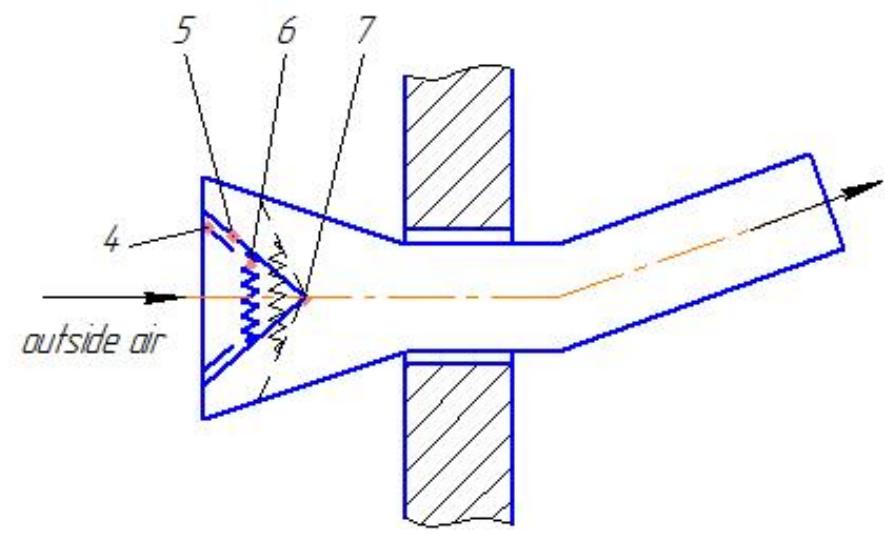

Fig. 2. Scheme of NVS intake device of the livestock building:

4 - stops; 5 - control valve flaps; 6 - tension spring; 7 - fixed shaft

The NVS intake device of livestock premises works as follows. External air is supplied through the intake pipe 1 into the air duct 2 and further into the livestock building 3 . With the calculated wind load the control valve 5, mounted on the fixed shaft 7 of the intake pipe, flaps under the influence of the calibrated tension spring 6 are in the position of maximum approach limited by stops 4 . When the wind force is increased above the calculated value, the valve flaps overcome the force of the tension spring and diverge, reducing the cross-section of the air intake pipe, and, accordingly, the volume of external air supply. In case of significant exceeding of the wind force, valve flaps contact the inner surface of the air intake pipe walls, the air intake pipe cross section is almost completely closed, and accordingly the supply of external air into the room through the supply device is stopped. When the wind force is weakened, the tension spring acts on the valve flaps and returns them to the initial position, thus providing the external air supply in the design mode.

In the cold season, external air is supplied at an angle to the horizon, as a result of which the jet will first move up and then fall down. Accordingly, the external air enters the room heated, which allows to avoid the feeling of "draft".

To identify conditions for effective functioning, it is necessary to justify the main parameters of the NVS supply device of the livestock building, to analyze the heat and mass exchange. The main parameter characterizing the operation of the supply device is the degree of heating of the external air in the duct, for determination of which a calculation scheme of heat and mass exchange in the proposed supply device is made (Fig. 3). 


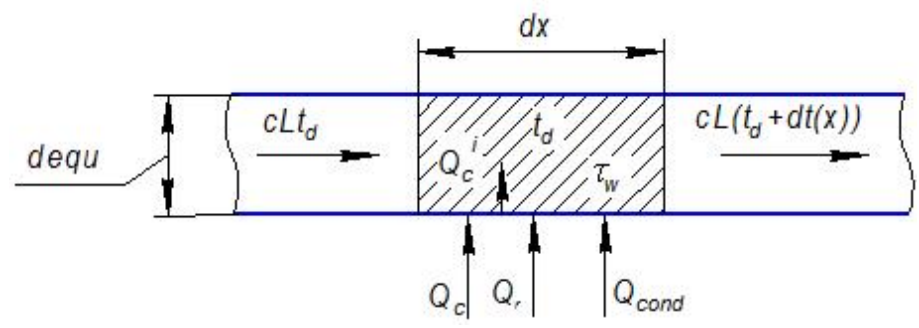

Fig. 3. Calculation diagram of heat and mass exchange in the proposed intake device

In accordance with the assumptions of the calculation scheme, the following heat balance equation [10] corresponds to:

$$
Q_{c}^{i}=Q_{c}+Q_{r}+Q_{\text {cond }},
$$

where $Q_{c}{ }^{i}$ - convective heat stream from the inner wall of the duct to the moving air, W; $Q_{c}$ - convective heat stream from the room air to the external wall of the duct, W;

$Q_{r}$ - radiant stream from the fences to the external surface of the duct and from animals to the external surface of the duct, W;

$Q_{\text {cond }}$ - heat generated during moisture condensation on the external surface of the duct, W.

The radiant flow from the fences to the outer surface of the air duct and from the animals to the outer surface of the air duct $Q_{r}$ is determined by the flows coming to the surface of the air duct from the animals and from the fences of the rooms. Calculations showed that the heat exchange by radiation in expression (1) can be neglected due to small values of the irradiation coefficients.

When the steam is cooled below the saturation temperature for a given pressure, the steam is condensed, i.e. converted to liquid, and condensation heat is generated, which is numerically equal to the heat of vaporization of $Q_{\text {cond }}$. In view of the small surface areas of the supply device, respectively, the area of condensate formation, this heat is not taken into account in further calculations [12].

Thus, of the three components of the heat balance equation, the convective heat flux from the room air to the outer wall of the duct $Q_{c}$ plays a significant role in formation of the temperature of the livestock building.

Convective heat exchange from the environment to the external wall of the duct is characterized by natural convection conditions. To express the convective stream of a duct element of length $d x$, the formula is used:

$$
Q_{c}=\alpha_{c}\left(t_{i a}-\tau_{w}\right) P d x,
$$

where $\alpha_{c}$-convection heat exchange coefficient, $\mathrm{W} \cdot \mathrm{m}^{-2}{ }^{\circ} \mathrm{C}$;

$t_{i a}-$ internal air temperature of the livestock building, ${ }^{\circ} \mathrm{C}$;

$\tau_{w}$ - duct wall temperature, ${ }^{\circ} \mathrm{C}$;

$P$ - duct perimeter, m;

$d x$ - duct length, $\mathrm{m}$.

Taking into account the heat exchange coefficient by natural convection calculated by means of known ratios for conditions of the livestock building [11], the ratio (2) will take form:

$$
Q_{c}=1.45 \sqrt[3]{\left(t_{i a}-\tau_{w}\right)}\left(t_{i a}-\tau_{w}\right) P d x,
$$

Heat exchange to the air moving in the duct occurs due to forced convection from the inner wall of the duct:

$$
Q_{c}^{i}=\alpha_{c}^{i}\left(\tau_{w}-t_{d}\right) P d x,
$$

where $\alpha_{c}{ }^{i}$ - heat transfer coefficient by convection of the inner surface of the duct, $\mathrm{W} \cdot \mathrm{m}^{-2} \cdot{ }^{\circ} \mathrm{C}$; $t_{d}$ - average temperature of the air moving in the duct, ${ }^{\circ} \mathrm{C}$.

The heat exchangecoefficient for forced convection $\alpha_{c}^{i}$ is determined in accordance with the criterion equation [11]: 


$$
N_{u}=0.035 \operatorname{Pr}^{1 / 3} \operatorname{Re}^{0.8},
$$

based on which the equation is obtained for determining the heat transfer coefficient for forced convection:

$$
\alpha_{c}^{i}=3.7 \frac{v^{0.8}}{d_{e q u}^{0.2}}
$$

where $d_{e q u}$ - equivalent duct diameter, $\mathrm{m}$;

$v-$ air speed $\mathrm{m} \cdot \mathrm{s}^{-1}$

Substituting expression (6) into expression (4), we get:

$$
Q_{c}^{i}=3.7 \frac{v^{0.8}}{\left(d_{\text {equ }}\right)^{0.2}}\left(\tau_{w}-t_{d}\right) P d x
$$

Difficulties in determining heat flows arise when finding the temperature of the duct wall, as it varies along the length of the duct and depends on the temperature of the internal air, temperature and flow rate of moving air. To determine the wall temperature in the first approximation, we substitute expressions (3) and (7) into expression (1):

$$
1.45\left(t_{i a}-\tau_{w}\right)^{1 / 3}\left(t_{i a}-\tau_{w}\right)=3.7 \frac{v^{0.8}}{\left(d_{\text {equ }}\right)^{0.2}}\left(\tau_{w}-t_{d}\right) .
$$

After linearization of the left side of equation (8), the relationship between the temperature of the duct wall and the temperature of the air moving in it can be represented as [10]:

$$
\tau_{w}=b t_{d}+a,
$$

where $a=f\left(t_{i a}, v, d\right)$ and $\mathrm{b}=f\left(t_{i a}, v, d\right)$ - linearization coefficients.

If the amount of the heat generated by friction of moving air against the duct is neglected, the following heat balance equation can be made for the duct section $d x$ :

$$
c L t_{d}+\alpha_{c}^{i}\left(\tau_{w}-t_{d}\right) P d x=c L\left(t_{d}+d t(x)\right),
$$

where $c$-specific heat of air, $\mathrm{J} \cdot(\mathrm{kgC})^{-1}$;

$L$ - air flow rate, $\mathrm{m}^{3} \cdot \mathrm{h}^{-1}$.

In this equality, the left part is the amount of heat entering the moving air due to heat exchange with the environment. The right part is the amount of heat received by the moving air, which resulted in the change in its temperature by the value $d t(x)$.

By substituting the resulting expression (9) and separating the variables, we get

$$
\frac{d t_{d}}{\left(a+b t_{d}-t_{d}\right)}=\frac{\alpha_{c}^{i} P}{c L} d x,
$$

Integrating this expression between the initial value $x=0$, when the external air temperature is $t_{n}$, i.e. $t_{n}=t_{d}$, to the current value $x$, when the moving air temperature $t(x)$, we obtain the desired relationship for determining $t(x)$ :

$$
\frac{A+B t(x)}{A+B t_{n}}=e^{B D x},
$$

where $A=a$;

$$
\begin{gathered}
B=(b-1) ; \\
D=\frac{\alpha_{c}^{i} P}{c L} .
\end{gathered}
$$

Then, the degree of heating of the external air in the supply device, which characterizes the initial parameters of the supply stream by temperature, is equal to: 


$$
\Delta t_{n}=t_{n}-t(x) .
$$

\section{Results and discussion}

On the basis of the received mathematical model (13) schedules of dependence of the external air heating degree $\Delta t_{n}$ from the air movement speed $v$ in the duct are constructed (Fig. 4), and the duct length $x$ (Fig. 5) with relative humidity $\varphi_{h}$ equal to $80 \%$, the diameter of the duct $d_{\text {equ }}=0.2 \mathrm{~m}$ and initial external temperature in the range $t_{n}=-5^{\circ} \mathrm{C} \ldots-20^{\circ} \mathrm{C}$ with a step $-5^{\circ} \mathrm{C}$. The speed characteristics of the natural ventilation system are taken as the initial data.

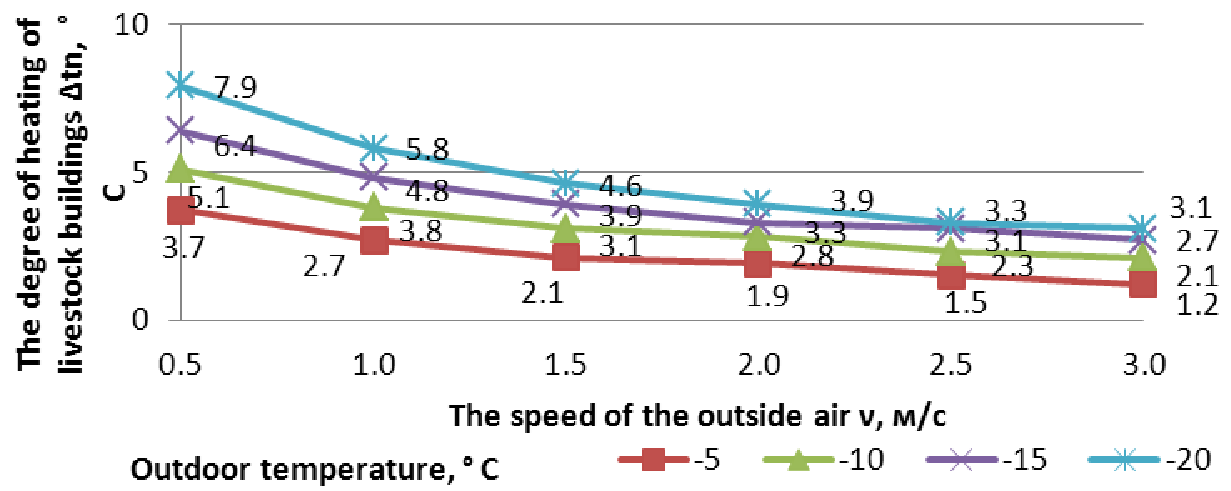

Fig. 4. Change of the degree of $\Delta t_{n}$ of external air heating depending on the speed $v$ of the air movement in the air duct

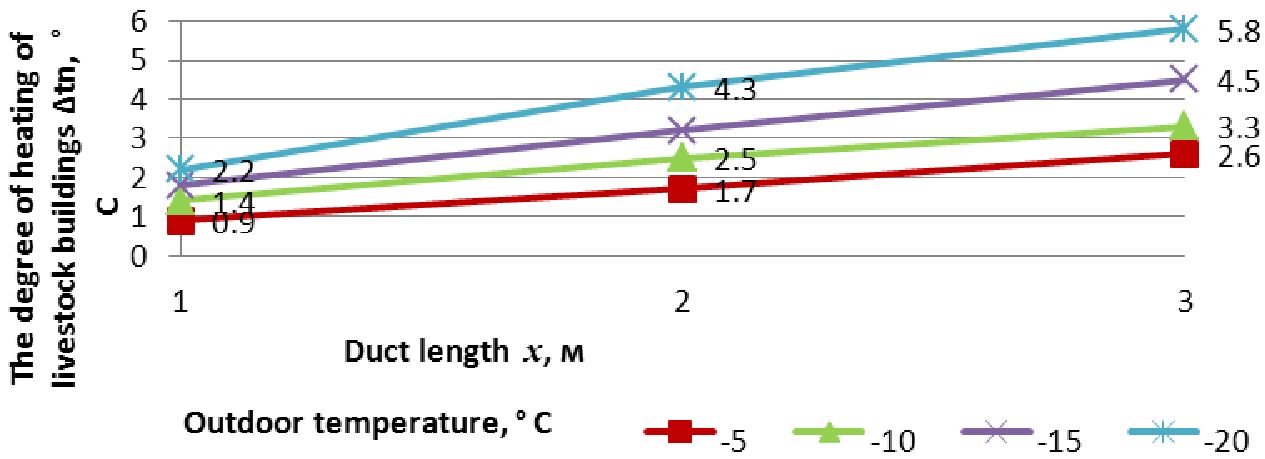

\section{Fig. 5. Change of the degree of $\Delta t_{n}$ of external air heating depending on the length of the duct $x$}

It can be seen from the graphs that the speed of the external air at its constant temperature has the strongest effect on the temperature of the livestock building. So, at a constant external temperature of$20^{\circ} \mathrm{C}$, the change of the air movement speed $v$ in the duct from $0.5 \mathrm{~m} \cdot \mathrm{s}^{-1}$ to $3 \mathrm{~m} \cdot \mathrm{s}^{-1}$ leads to the heating degree decrease $\Delta t_{n}$ of external air from $7.9^{\circ} \mathrm{C}$ to $3.1^{\circ} \mathrm{C}$ respectively. Such decrease of the heating degree does not meet the zootechnical standards. When supplying external air with winter temperature of $-20^{\circ} \mathrm{C}$ and the internal temperature of the livestock building is $10^{\circ} \mathrm{C}$ by mixing it with warm air at the outlet of the duct, the heating degree $\Delta t_{n}$ is $2.2^{\circ} \mathrm{C}$ at the duct length $x$ of $1 \mathrm{~m}$, and at the duct length of $3 \mathrm{~m}$ it is $5.8^{\circ} \mathrm{C}$. With increasing the duct length $\boldsymbol{x}$, the heating degree $\Delta t_{n}$ of the external air increases and the standard temperature of the livestock building is provided.

\section{Conclusions}

1. The NVS air supply unit of the livestock building is proposed for windy weather and cold season, the air intake pipe of which is equipped with an adjustment valve to prevent overcooling of the lower zone of the room in windy weather, and the duct is elongated and installed parallel to the pitched roof to prevent a significant temperature difference in the livestock building.

2. The graph shows the dependence of the external air heating in the intake device on the speed of the external air and the length of the duct. It was found that the length of the duct equal to $3 \mathrm{~m}$ provides the standard temperature of the livestock building in windy weather and cold seasons due to the increase in the temperature of the external air. 
3. Based on theoretical studies, it is necessary to develop a constructive solution for the NVS intake device and conduct its experimental research in order to check the theoretical justification of the heat and mass exchange in it.

\section{References}

[1] Капустин Н.И., Капустин В.Н., Бырдин И.Н. Обоснование элементов приточно-вытяжной вентиляции животноводческих помещений с автоматическим регулированием (Justification of elements of supply and exhaust ventilation of livestock premises with automatic regulation). Вестник Алтайского государственного аграрного университета, 2009, No7 (57), pp. 58-61 (In Russian).

[2] Мамедов Э.С. Обеспечение температурно-влажностного режима в животноводческих помещениях горной зоны Азербайджана (Provision of temperature and humidity con ditions in the livestock areas of the mountain zone of Azerbaijan). Сибирский вестник сельскохозяйственной науки, 2015.No4 (425), pp. 106-111 (In Russian).

[3] Капустин Н.И., Садов В.В. Пути создания регулируемой вентиляции в животноводческих помещениях Алтайского края в зимний период (Ways to create controlled ventilation in livestock premises of the Altai territory in the winter)). Вестник Алтайского государственного аграрного университета, 2019. № 9 (179),pp. 173-179 (In Russian).

[4] Маркаряпц Л.М., Никитин А.М. Улучшение микроклимата путем совершенствования вентиляции (Improving the microclimate by improving ventilation). Вестник Брянской государственной сельскохозяйственной академии, 2012. No 1, pp. 37-40 (In Russian).

[5] Максимов Н.В. Система естественной вентиляции с утилизацией теплоты (Natural ventilation system with heat recovery). Технологии и технические средства механизированного производства продукции растениеводства и животноводства, 2004, № 76, pp. 170-177 (In Russian).

[6] Позин Г.М., Самсонов А.Н. Исследование приточного устройства системы естественной вентиляции животноводческого помещения (Study of the supply device of the natural ventilation system of livestock premises). Техника в сельском хозяйстве, 2007, No 5, pp. 12-15 (In Russian).

[7] Шкуратов Г.В., Купреенко А.И. Вентиляционно-отопительные панели как основа обеспечения микроклимата животноводческих помещений (Ventilation and heating panels as the basis for ensuring the microclimate of livestock premises). Конструирование, использование и надежность машин сельскохозяйственного назначения, 2013. № 1 (12), pp. 10-16 (In Russian).

[8] Зубков И.В. Изучение метода энергосбережения в системах вентиляции животноводческих ферм (Study of the method of energy saving in ventilation systems of livestock farms). Актуальные направления научных исследований XXI века: теория и практика, 2018, Vol. 6. No 3 (39), pp. 423-429 (In Russian).

[9] Andonov K., Daskalov P., Martev K. A New approach to controlled natural ventilation of livestock buildings. Biosystems Engineering, vol. 84 (1), 2003, pp. 91-100.

[10]Патент RU № 2008108056. Приточное устройство системы естественной вентиляции животноводческого помещения (A patent RU 2008108056.Supply device of natural ventilation system of livestock premises). Авторы: Максимов Н., Козлова Н., Самсонов А., 2009. (In Russian).

[11] Ануфриев Л.Н., Кожинов И.А., Позин Г.М. Теплофизические расчеты сельскохозяйственных производственных зданий (Thermophysical calculations of agricultural production buildings). Moscow, 1974, 216 p. (In Russian).

[12] Брдлик П.М., Кожинов И.А., Петров Н.Г. Пособие по расчету тепло- и массобмена при конденсации пара из влажного воздуха на внутренней поверхности наружных стен (Manual for the calculation of heat and mass exchange during condensation of steam from moist air on the inner surface of external walls). Moscow, 1967, 10 p. (In Russian). 